\title{
The Child's Best Interest: A Review of Australian Juvenile Justice Legislation
}

\author{
Vanessa Coppins $^{1}$, Sharon Casey ${ }^{2, *}$ and Alan Campbell ${ }^{1}$ \\ ${ }^{1}$ University of South Australia; ${ }^{2}$ Deakin University, Australia
}

\begin{abstract}
The United Nations Convention on the Rights of the Child (UNCRC) is a universally agreed upon set of obligations and standards which recognise that children, independent of adults, are born with and entitled to the fundamental freedoms and rights that are inherent to all human beings. Article 3 of the UNCRC decrees that the best interests of the child must be a primary consideration of executive authorities, law-makers, judicial bodies, and relevant private institutions in all actions taken in matters concerning children. A review of relevant Australian State and Territory juvenile justice legislation revealed considerable disparity in interpretation and inclusion of the best interests principles. What the analysis revealed was that whereas the procedural rights of a young offender are met, much of the legislation does not extend to ensuring that what happens once the young person enters the juvenile justice system is in his or her best interests.
\end{abstract}

Keywords: Human rights, young offenders, best interests of the child.

\section{INTRODUCTION}

Built on various legal systems and cultural values, and negotiated over a ten year period by governments, nongovernment organisations, human rights activists, lawyers, health specialists, social workers, educators, experts on child development, and religious leaders, the United Nations Convention on the Rights of the Child (UNCRC) is a universally agreed upon set of obligations and standards which recognise that children, independent of adults, are born with and are entitled to the fundamental freedoms and rights that are inherent to all human beings (United Nations Children's Fund [UNICEF], 2008). Coming into force in 1990, it serves as a common reference or benchmark against which progress in meeting human rights standards for children can be measured and assessed. The UNCRC articulates, in 54 Articles and two Optional Protocols, the basic rights to which children worldwide are entitled: survival, development, protection, and participation. Underpinning these rights are the four guiding principles of non-discrimination (Article 2), adherence to the best interests of the child (Article 3), respect for life (Article 6), and regard for the child's opinion (Article 12).

The focus of this paper is on Article 3 (adhering to the best interests of the child) and how this principle informs other UNCRC standards as they relate to Australian young people who come before the criminal justice system (Articles 37 and 40). Specifically, the paper examines how the principle of best interests is enshrined in and informs Australian

*Address correspondence to this author at the School of Psychology, Deakin University, PO Box 630, Oakbank South Australia 5243, Australia; Tel: +6135227 8715; Fax: +6135227 78621;

E-mail: sharon.casey@deakin.edu.au
State and Territory legislation ${ }^{1}$. As a relevant, national best interests framework does not currently exist in Australia, various writings (e.g., UN status reports) were examined for their recommendations on what should be considered when rendering best interests decisions, and a criterion was created in order to compare, contrast, and critique the State and Territory Acts.

\section{BACKGROUND}

There exist a range of international conventions, standards, treatises and rules articulating specific rights which, if applied, form a solid foundation for the operation of any juvenile justice system. For example, the United Nations Standard Minimum Rules for the Administration of Juvenile Justice (1985; the Beijing Rules) are a broad set of principles for its governance. The Rules include reference to the importance of an offender's well-being and the need to ensure that the principle of proportionality is applied (Rule5). Reference is also made to the young person's right to privacy (Rule 8), to legal assistance (Rule 15), and the need to understand and participate in the legal process (Rule 14). The Beijing Rules operate within the framework of the United Nations Guidelines for the Prevention of Juvenile Delinquency (1990a; the Riyadh Guidelines) and the United Nations Rules for the Protection of Juveniles Deprived of their Liberty (the Havana Rules; 1990b).

\footnotetext{
${ }^{1}$ Australia has nine legal systems: the six state and two territory systems and one federal system. The federal government has exclusive power to make laws on matters such as trade and commerce, taxation, defence, external affairs, and immigration and citizenship; it also has concurrent powers (i.e., where both state and federal government are able to enact laws). The states and territories have independent legislative power in all matters not specifically assigned to the federal government (although where inconsistency between federal and state or territory laws occurs, federal laws prevail). Criminal law (including juvenile justice) is, therefore, under the jurisdiction of each State or Territory government.
} 
Perhaps the most well-known (and influential) instruments to emerge from the United Nations, the Council of Europe and other bodies on children's rights is the United Nations Convention on the Rights of the Child (UNCRC; 1989). The first legally-binding international covenant to incorporate the full range of individual rights, the UNCRC serves to strengthen the protection rights outlined in the Beijing Rules by providing a range of due process standards which recognize not only the child's right to a fair trial, but also the need to adapt the trial process to meet the needs and rights of children. As such, it provides comprehensive minimum standards for the treatment of all children and its introduction has resulted in the establishment of a "near global consensus that all children have a right to protection, to participation, to personal development and to basic material provision (Muncie, 2008, p.45).

In fact,

The underlying principles of the UNCRC provide the standards applicable to all actions concerning children in the healthcare, educational, legal, civil, and social service domains. Whilst the role, authority, and responsibility of parents and guardians towards children remain fundamental, the UNCRC also implies that a child is neither the property of his or her caregivers nor the passive recipient of charity. In other words, the child is conceived as a human being who is the valid recipient of his or her own intrinsic rights (Van Bueren, 1998).

Treaties like the UNCRC are negotiated among United Nations Member States and are legally binding on the individual States which subsequently become party to the instrument. This occurs either by signature ${ }^{2}$ and ratification ${ }^{3}$ (see UNICEF, 2006a). The UNCRC has been ratified by 192 countries including every UN Member State with the exception of the US and Somalia. In fact, it is the most extensively ratified UN document ever produced (Goldson \& Muncie, 2006; UNICEF, 2006b). Australia supported the UNCRC through its various stages and was one of the first countries to ratify it (December 1990) after gaining the approval of the Australian States and Territories. It became binding in Australian Federal law on January 16, 1991 and was declared a relevant international instrument under the Human Rights and Equal Opportunity Act 1986 (The National Children's and Youth Law Centre, 2004).

\section{ARTICLE 3: BEST INTERESTS OF THE CHILD}

The notion of best interests of the child is enshrined in the UNCRC in Article 3 (see Table $\mathbf{1}$ below) and is pivotal as a core principle that underpins the standards set in subsequent Articles (Freeman, 2007). It decrees that in all actions taken by executive authorities, law-makers, judicial bodies, and relevant private institutions in matters concerning children, the best interests of the child must be a primary consid-

\footnotetext{
2 'Signature' constitutes a preliminary endorsement by a member State but does not commit a State to a binding legal obligation. Instead, it demonstrates a commitment to examine the treaty domestically and to consider ratification. While not equal to ratification, it obliges a State to refrain from acts that would defeat and undermine the instruments objective and purpose (UNICEF, 2006a).

3 'Ratification' signifies agreement by the member State to be legally bound by the treaty's terms. This requires the State to first sign the treaty and then fulfil its own national legislative requirements. Once the appropriate nation head (e.g., Head of State or Government) follows domestic constitutional procedures and makes a formal decision to become a State party to a treaty, the ratification instrument, along with a signed and sealed letter referring to the decision, is prepared and deposited with the UNs Secretary-General in New York.
}

eration. However, that which constitutes best interests has not been defined in either past Conventions nor the current one, and is perhaps a contributing factor to justifications of gross violations of child rights in the name of 'best interests'. In Australia, for example, the forced removal of Indigenous ${ }^{4}$ children from their families and placement in institutions as a method of introducing these children to 'civilisation' was considered to be in the young Indigenous person's best interest. While it is not difficult to see how this example is an obvious misuse of the principle, other factors, such as the resources, developmental level, or the cultural traditions of a country may skew that which is considered to be the child's best interests. For example, the food and income of many families in developing countries is contingent upon every capable family member, including children, working in order for the family to survive. It is known that some work can be hazardous and exploitative for children, and human rights doctrines (including the UNCRC) decree that children have the right to be free from harm and exploitation, but the same doctrines state that the child has a right to life and to survival. This raises an important dilemma: should the child risk survival to be free from harm and exploitation, or endure it and live? (Table 1).

The UNCRC does not offer a definitive statement of what is in a child's best interest in any given situation but provides instead a framework that defines the application of the principle. Thomas Hammarberg (2008, p.5), Commissioner for Human Rights (Council of Europe), stated that "though necessarily general and incomplete, a reasonable first building block towards the definition of what is in the best interests of the child is the sum total of the norms in the Convention". In other words, the best interests principle is a governing rule which is defined through its application to other Convention Articles. For example, if one considers in combination Articles $5^{5}, 8(1)^{6}$, and $30^{7}$, it is in the best interests of an Indigenous child to be raised in an Indigenous community (Office of the United Nations High Commissioner, 1990). Moreover, while such a framework has been criticized as being vague and ambiguous, it would seem no less so than other concepts or principles within the legal system, particularly those relating to the treatment of children. This was articulated by the majority in the Australian High Court decision in Marion's Case [1992]: "it is true that the phrase 'best interests of the child' is imprecise, but no more

\footnotetext{
${ }^{4}$ Consistent with ratification, accession signifies an agreement to be legally bound by the terms of a particular treaty. It has the same legal effect as ratification, but is not preceded by an act of signature (same reference as signature and ratification).

${ }^{5}$ Article 5: States Parties shall respect the responsibilities, rights and duties of parents or, where applicable, the members of the extended family or community as provided for by local custom, legal guardians or other persons legally responsible for the child, to provide, in a manner consistent with the evolving capacities of the child, appropriate direction and guidance in the exercise by the child of the rights recognized in the present Convention.

Article 8(1): States Parties undertake to respect the right of the child to preserve his or her identity, including nationality, name and family relations as recognized by law without unlawful interference.

7 Article 30: In those States in which ethnic, religious or linguistic minorities or persons of indigenous origin exist, a child belonging to such a minority or who is indigenous shall not be denied the right, in community with other members of his or her group, to enjoy his or her own culture, to profess and practise his or her own religion, or to use his or her own language.

${ }^{8}$ In Marion's case, it was held that courts may exercise a general supervisory role to act to protect the best interests of the child. This guardianship jurisdiction permits courts to overrule parents (and/or their Gillick competent children) who have refused treatment, and to authorise treatment based on the concept of 'best interests'. In addition, courts are capable of adjudicating disputes that relate to a child's proposed medical treatment in the event of a conflict between parents and children, or involving parents, children and medical practitioners.
} 
Table1. Article 3: Best Interests of the Child

\begin{tabular}{|c|c|}
\hline Article No. & Description \\
\hline $3(1)$ & $\begin{array}{l}\text { In all actions concerning children, whether undertaken by public or private social welfare institutions, courts of law, administrative } \\
\text { authorities or legislative bodies, the best interests of the child shall be a primary consideration. }\end{array}$ \\
\hline $3(2)$ & $\begin{array}{l}\text { States Parties undertake to ensure the child such protection and care as is necessary for his or her well-being, taking into account the } \\
\text { rights and duties of his or her parents, legal guardians, or other individuals legally responsible for him or her, and, to this end, shall take } \\
\text { all appropriate legislative and administrative measures. }\end{array}$ \\
\hline
\end{tabular}

so than the 'welfare of the child' and many other concepts with which the courts must grapple".

\section{CHILDREN IN CONFLICT WITH THE LAW}

Under the principles of the UNCRC, the phrase "children in conflict with the law" refers to individuals below the age of 18 who come into contact with the justice system as the result of being suspected, accused, or charged with committing a crime (UNICEF, 2006c). Most children or young people in the juvenile justice system have committed minor crimes or petty offences such as vagrancy, truancy, running away from home or underage drinking. Otherwise known as 'status offences', these are not generally considered criminal when committed by adults. Three Articles are of particular importance here, one of which speaks to the right of children to play an active role in any process which concerns them (Article 12) and the other two (Articles 37, and 40) specifically address the issue of juvenile justice (see Table 2). According to Article 12, children have the right to freely express their views in all matters that affect them and, more importantly, that their viewpoint should be given due weight in accordance with their age and maturity. These rights impose clear legal obligations on State parties to not only recognise this right, but also to either directly "guarantee this right, or adopt or revise laws so that this right can be fully enjoyed by the child" (Office of the United Nations High Commissioner, 2009, p. 8). Both Article 3 and Article 12 are, according to the UN Committee ${ }^{9}$ on the Rights of the Child (the 'Committee'), central to implementing the provisions in Articles 37 and 40. (Office of the United Nations High Commissioner, 2007) Paramount to this consideration is that children and adults differ in their emotional, intellectual and psychological capacities and needs, and such differences constitute the basis for the lesser culpability of a child in conflict with the law. With this in mind, the committee states that a child's best interests are better articulated and represented by the use of restorative justice principles than they are through the employment of retribution philosophies (Table 2).

As compared to retribution with its focus on blame, guilt and punishment, restorative justice focuses on reconciliation, restoration, and healing (Zehr, 1990). An outgrowth of the victim rights movement, restorative justice incorporates many of the non-punitive Indigenous practices of mediation, dialogue, reintegration, and reparation in the resolution of conflict (Blomberg\&Lucken, 2009). The underlying philosophy is that the cause of criminal behaviour can be found in the societal alienation of certain members. Moreover,

\footnotetext{
${ }^{9}$ The Committee is the elected body of experts designed to examine the progress made by State parties in achieving their obligations to the UNCRC.
}

while it is the responsibility of each individual to make positive choices, no one person exists separate to society and it is, therefore, the community's responsibility to bring the errant individual back into a harmonious relationship with him- or herself as well as the broader society within which the individual lives. Restorative justice therefore embraces the principle of balance: the balancing of, in equal measures, victim, community and offender needs with the ultimate aspiration of undoing the harm and damage caused by an offence (Achtenberg, 2000).

Table 3 contrasts the underlying assumptions of the restorative paradigm with the more traditional retribution framework. This comparison highlights several important elements of the restorative justice approach. First, the offender is not defined by his or her deficits but by the capacity to make reparation. Reparation is the action of repair or renewal and is a theological concept closely related to atonement and satisfaction (Herbermann, 1913). Second, instead of an adversarial "contest" between the offender and the State directed by systematic rules, there is a focus on open dialogue and negotiation. Finally, that reintegration has been included into the restorative framework means it looks to the future of all those affected by a crime.

A cornerstone of the restorative justice approach is the use of conferencing as a pre-court diversion. Based on community justice principles, it involves a facilitated face-to-face meeting between the offender and victim (at a minimum), the goal of which is to repair harm and restore the community to a pre-crime state of well-being. During the meeting, participants are encouraged to tell their stories about the offence, ask questions and receive answers in an attempt to understand not only what happened but why it happened. According to the Judicial Council of California (2006), the benefits of restorative conferences include relationships being restored or not being further damaged; greater satisfaction with the justice system; greater amounts of restitution being paid; a reduced rate of recidivism; reduced fear experienced by the victims of crime; the victim's and offender's sense of community belonging is restored; victims receive restitution agreements they consider fair because they have helped in their creation; and offenders are fully involved in the decision-making processes. The benefits of taking a restorative rather than retributive approach have been shown in two large meta-analytic studies. For example, Smith, Goggin, and Gendreau (2002) found that as compared to offenders serving a community sentence, not only was recidivism greater for those serving a prison sentence but the longer the sentence, the greater the likelihood of recidivism. Smith et al. also found that electronic monitoring, compulsory drug testing, and boot camps had no significant effect on recidi- 
Table 2. Summary of Articles 12, 37 and 40 of the United Nations Convention on the Rights of the Child

\begin{tabular}{|c|c|}
\hline Article 12 & The Child's Opinion \\
\hline & $\begin{array}{l}\text { The child has the right to express his or her opinion freely and to have that opinion heard and be taken into account in any matter or } \\
\text { procedure affecting the child }\end{array}$ \\
\hline \multirow[t]{2}{*}{ Article 37} & Deprivation of Liberty \\
\hline & $\begin{array}{l}\text { Children are to be deprived of liberty only as a last resort and for the shortest appropriate period of time. Any child who is deprived of } \\
\text { liberty shall be separated from adults unless it is considered in the child's best interests not to do so. A child who is detained shall have } \\
\text { legal and other assistance as well as contact with the family }\end{array}$ \\
\hline \multirow[t]{2}{*}{ Article 40} & Administration of Juvenile Justice \\
\hline & $\begin{array}{l}\text { A child in conflict with the law has the right to treatment which promotes the child's sense of dignity and worth, takes the child's age } \\
\text { into account and aims at his or her reintegration into society. The child is entitled to basic guarantees as well as legal or other assistance } \\
\text { for his or her defence. Judicial proceedings and institutional placements shall be avoided wherever possible }\end{array}$ \\
\hline
\end{tabular}

Table 3. Comparison of Retributive and Restorative Justice Philosophies (Adapted from Zehr, 1990)

\begin{tabular}{|c|c|}
\hline Retributive Justice & Restorative Justice \\
\hline Offender accountability defined as taking punishment. & Accountability defined as assuming responsibility and taking action to repair harm \\
\hline $\begin{array}{l}\text { Punishment is effective. } \\
\text { a. Threat of punishment deters crime. } \\
\text { b. Punishment changes behaviour. }\end{array}$ & $\begin{array}{l}\text { Punishment alone is not effective in changing behaviour and is disruptive to community } \\
\text { harmony and good relationships }\end{array}$ \\
\hline The offender is defined by deficits. & The offender is defined by capacity to make reparation \\
\hline $\begin{array}{l}\text { Focus on establishing blame, on guilt, on past (did } \\
\text { he/she do it?). }\end{array}$ & Focus on problem solving, on liabilities/obligations, on future (what should be done?). \\
\hline Emphasis on adversarial relationship. & Emphasis on dialog and negotiation. \\
\hline Imposition of pain to punish and deter/prevent. & Restitution or reparation as a means of restoring both parties; goal of reconciliation/restoration. \\
\hline Response focused on offender's past behaviour. & Response focused on harmful consequences of offender's behaviour; emphasis on reintegration \\
\hline Dependence upon proxy professionals. & Direct involvement by participants. \\
\hline
\end{tabular}

vism rates. In a second meta-analysis, Bonta, WallaceCapretta, Rononey and McAnoy (2002) evaluated the impact of restorative justice programs on recidivism rates and found a significant reduction in recidivism associated with such programs. Moreover, little variation was found in the effect size for different types of program (e.g., victim-offender mediation programs, restitution). Although the authors point out that the majority of restorative justice programs reviewed involved offenders who were in the lower risk range for recidivism, they also note that improved outcomes for this group is contrary to the risk principle (i.e., that low risk offenders who engage in treatment have an increased likelihood of re-offending). By way of explanation they postulated that the restorative justice principles involved (e.g., accepting responsibility, payment of restitution) have a greater deterrent effect for this group of offenders. This is particularly relevant to juvenile offenders, the majority (approximately $90 \%$ ) of whom will "age out" of crime by late adolescence (Gottfredson \& Hirshi, 1990). Using restorative justice principles can, therefore, not only reduce recidivism during this peak period of offending, but also helps young people avoid becoming entrenched in a juvenile justice sys- tem that carries with that carries within it the stigma of being a "criminal".

\section{AUSTRALIAN THAT CARRIES WITHIN IT THE STIGMA STATE AND TERRITORY JUVENILE JUS- TICE LEGISLATION}

What follows is an examination of relevant Australian State and Territory juvenile justice legislation for the inclusion of best interest principles. As previously noted, the UNCRC defines the principle of best interests through its application to other Convention Articles but does not offer a definitive criterion for what should be considered in best interests determinations. With the intent to aid would-be decision makers, a criterion was developed based on (a) Articles 3, 12, 37 and 40, (b) responses by the UN Committee on the Rights of the Child to various status reports ${ }^{10}$ (see, inter alia, United Nations, 2008, 2009; United Nations Children's Fund 2006a, 2006b) and (c) the principles of restorative justice, to enable an examination of State and Territory

\footnotetext{
${ }^{10}$ Each State party is required to periodically send the UN Committee on the Rights of the Child reports detailing the national situation of children's rights. The Committee examines each report and raises concerns or makes recommendations to the State party
} 
legislation. Specifically, the provisions of each relevant Act were examined for their inclusion of identified best interest considerations: Act provisions were considered compliant if they echoed the general ethos of the considerations identified in the criterion. The outcome for each state and territory Act is discussed below and summarised in Table 4.

Australian Capital Territory. Youth justice is primarily administered under the Children \& Young People Act $2008^{11}$; the Crimes (Restorative Justice) Act 2004 was also considered because it dictates whether an offender is eligible for a restorative justice conference. As shown in Table 4, the Children \& Young People Act has an extensive inclusion of the best interest principle and states that the decision-maker must regard the best interests of children and young people as paramount in all decisions that directly and indirectly affect them. In fact, it is the only Australian legislation of this type to include all considerations of best interests. That said, it does not meet the criteria on one count: The only provision for keeping children deprived of their liberty separate from adults is (a) during transportation to and from detention and court and (b) while at court. Another shortcoming is that while provision is made for the use of conferences, these are not defined by a restorative justice framework but referred to as 'family-group conferences' (which do not include victims). The object of the conference is to encourage the child and child's family to take part in decisions, to increase support for the child or young person by family members and significant people, and to help the child's transition back into society.

The central tenet of the Crimes (Restorative Justice) Act is that the offender must accept responsibility for their criminal actions. Types of reparation include an agreement for financial compensation, an apology, a work plan, or plan to address offending behaviour. Involvement in the conference is voluntary and does not prevent the offender from pleading guilty; nor does participation influence sentence severity. For example, a court is not required to reduce the severity of any sentence subsequent to participation in a conference; similarly, choosing not to be involved in a conference cannot resulted in a sentence of increased severity. What is disappointing about this particular Act is that despite its claim of focussing on 'restorative justice', it appears to have adopted only some of these principles. For example, while the objectives include enhancing "the rights of victims of offences by providing restorative justice as a way of empowering victims to make decisions about how to repair the harm done by offences" and setting up "a system of restorative justice that brings together victims, offenders and their personal supporters in a carefully managed, safe environment", Table 3 clearly shows that it does not (a) make the needs of the young offender a priority and (b) show any consideration for the youth's reintegration into the community. In fact, when considered in its entirety, not promoting the needs and interests of victim, community and offender in equal measures could be interpreted as contradicting a principle that is integral to restorative justice paradigms.

\section{New South Wales}

Relevant Acts in this jurisdiction are the Young Offenders Act 1997 and the Children (Criminal Proceedings) Act 1987.

\footnotetext{
${ }^{11}$ The Act also encompasses care and protection principles.
}

The object of the Young Offenders Act was to establish a scheme that provides an alternative process to court proceedings for children who commit certain offences through the use of cautions, warnings and youth justice conferences. Conferences are used to (i) enable a community-based, negotiated response to offences involving all the affected parties; (ii) emphasise restitution by the offender and the acceptance of responsibility by the offender for his or her behaviour, and (iii) meet the needs of victims and offenders. All three principles are fundamental to a restorative justice paradigm. Consistent with UNCRC suggestions, this Act incorporates two best interests principles: use of the least restrictive form of sanction and a preference for alternative and appropriate means of adjudication.

The commencement, conduct and outcome of court proceedings involving children and young people not diverted under the above Act are principally governed by the Children (Criminal Proceedings) Act. This Act incorporates two elements of the UNCRC, namely the capacity for children to have rights and freedoms before the law that are equal to those of adults (including the rights to be heard and to participate in processes that lead to decisions that affect them); the Act also promotes restorative justice principles, stipulating that children accept responsibility for their actions, make reparation (where possible) for their actions, and that children who commit crimes be assisted with reintegration into the community. However, as shown in Table 4, the Act lacks commitment to (a) best interests generally, (b) the promotion of dignity, and (c) prioritising the needs of the young offender. For example, while Section 33 of the Act permits the court to take various actions other than detention, it fails to articulate or imply that the court should use liberty deprivation only as a last resort and for the shortest appropriate time.

\section{Northern Territory}

The Youth Justice Act is a complete legislative framework that covers all facets of the juvenile justice system, from investigation of offences and pre-court diversion, to court proceedings and sentencing, community supervision orders, detention centres and interstate transfers. The Act's guiding principles involve restorative justice objectives and include the encouragement of accountability and responsibility, an emphasis on reintegration, and a stipulation that a balanced approach needs to be taken between the needs of youth, victim and community. As such, the Act is very UNCRC-orientated in that its provisions state that (a) criminal proceedings should not be instituted or continued if there are alternative means for dealing with a matter, and (b) a youth should only be kept in custody for an offence as a last resort and for the shortest appropriate period of time. Whilst the Act does not explicitly articulate the primacy of best interests, it nonetheless appears to apply these in a comprehensive manner.

\section{Queensland}

The Juvenile Justice Act 1992 includes a charter of 20 juvenile justice principles that guide officers in the operation and application of the Act, and includes stipulations (a) that the youth justice system should uphold the rights of children, keep them safe and promote their physical and mental wellbeing (s.2), (b) that children being dealt with under this Act should be treated with respect and dignity, including while 
Table 4. Best Interests Principles in State and Territory Legislation

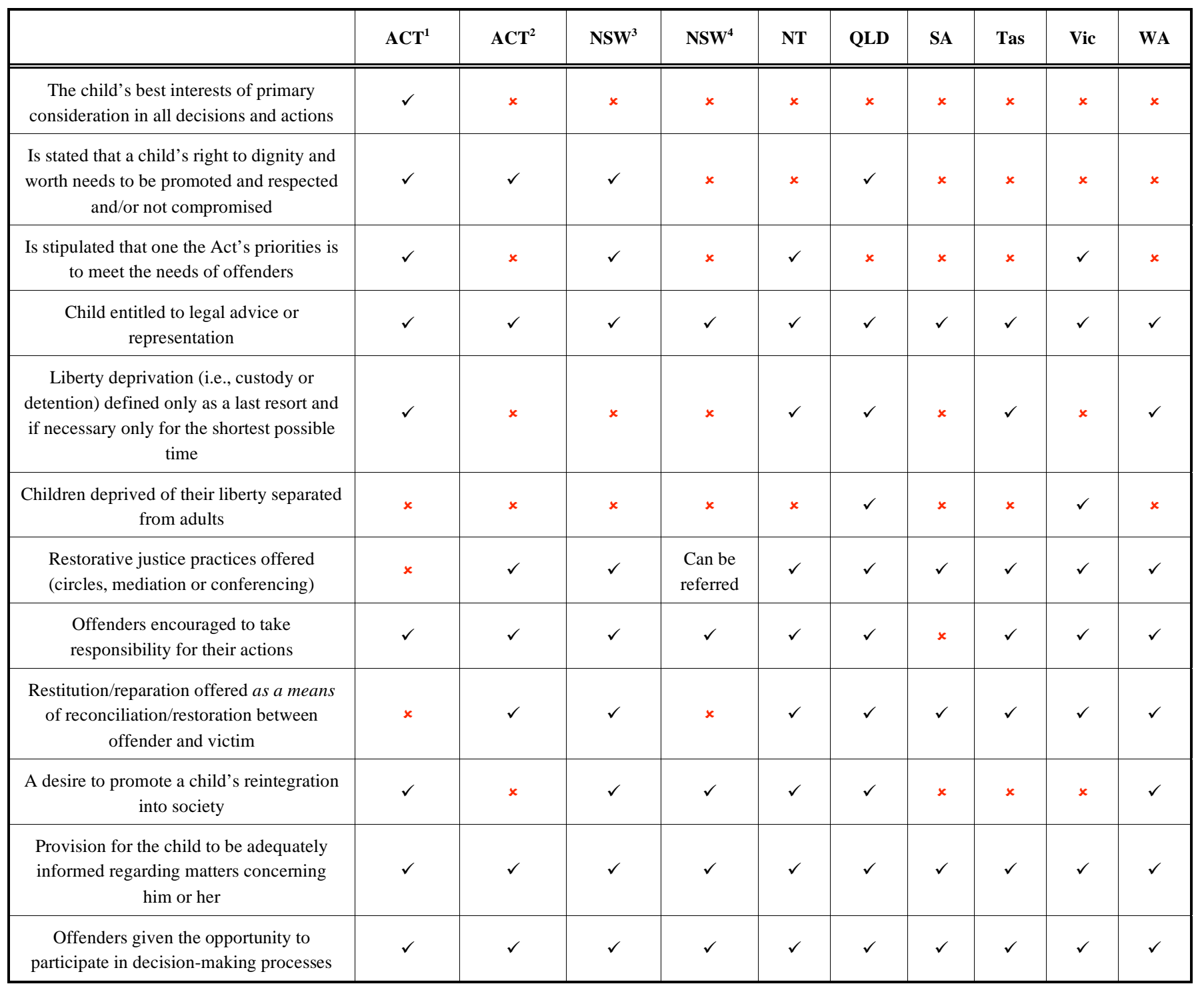

Note: 1 = Children \& Young People Act 2008; 2 = Crimes (Restorative Justice) Act 2004; 3 = Young Offenders Act 1997; 4 = Children (Criminal Proceedings) Act 1987.

the child is in custody (s.3a), and (c) that a child detained in custody should only be held in a facility suitable for children (s.18). According to the definitions of the best interest principle as articulated in this review, this Act has the highest inclusion and application of the principle (see Table 4).

\section{South Australia}

Whereas the Queensland legislation is the most consistent with the principles enshrined in the UNCRC, the South Australian Young Offenders Act 1993 is the least. This Act gives primacy to (a) making the young person aware of their obligations under the law, and conscious of the consequences for any breaches, and ensuring that the community is protected from that behaviour. (b) In fact, the only best interests provisions are the entitlement to legal representation, and that the child be kept informed of, and have the opportunity to participate in, the decision-making process. No reference is made to restorative justice principles, and while the Act does state that "compensation and restitution should be provided, where appropriate, for victims of of- fences committed by youths", this falls substantially short of the values inherent in restorative justice paradigms. For example, while the objectives set out in s.3 are guiding standards intended to be applied across all sections of the Act, these are in conflict with the principles of conferencing predicated on restorative justice principles. As previously observed by Wundersitz and Hunter (2005), the Act's objectives contain no reference to these principles and thus subsequently fails to provide adequate legislative guidelines for this practice.

\section{Tasmania}

A major emphasis of this State's Youth Justice Act 1997 is pre-court diversion, with detention stipulated as suitable only as a last resort. Restoration or reparation of harm done by the offender is achieved through the involvement of offender, victim, and the community who participate in community conferences. That said, community protection and the enhancement of victim rights is the predominant principle informing these conferences. The Act also fails to in- 
clude provisions for the best interests and needs of the young offender, nor is there any consideration of the child's reintegration into society.

\section{Victoria}

The Children, Youth and Families Act 2005 also emphasises a diversionary approach, and is the only Act to stipulate the prioritisation of young offender needs. However, what is perplexing, and arguably discriminatory, about the Act is that it is designed to recognise the inherent rights of children - as stipulated by the UNCRC - but many of these rights apply only to children in care and protection situations (which are also covered under this Act) and not those involved in the criminal justice system. That said, it is one of only two Acts (Queensland is the other) which state that children deprived of their liberty are to be separated from adults (other Acts stipulate that this extends only to court cells). It also includes the option of pre-sentencing group conferences that, despite a lack of reintegration emphasis, include the opportunity for the offender to take responsibility and make reparation. And whilst the Act does not articulate that liberty deprivation is to be used only as a last resort, its sentencing principles distinguish between the developmental needs of children as separate from adult needs, and highlight matters that the court must take into consideration when determining a sentence (e.g., the need to minimise the stigma of receiving a court order).

\section{Western Australia}

The Young Offenders Act 1994 makes no reference to the best interests principle, lacks a focus on the specific needs of young offenders, does not stipulate the promotion and respect of a child's dignity, and states that youths over the age of 16 years can reside in the same prison as adults (although they cannot share the same cell). Despite these limitations, the Act does make provision for Juvenile Justice Teams (JJT) to deal with children and youths who have committed minor offences or are in the early stages of offending (Western Australian Department of Correctional Services, 2006). The JJT process follows the same principles of a restorative conference in that the young offender, his or her parents, and the victim(s) meet face-to-face to discuss the offence and agree on penalty. The teams offer young people a choice: to participate and complete the mediation process or to have the matter dealt with in court. If the young offender chooses to participate he or she must accept responsibility for their actions; if they do not, the matter is referred back to the courts. JJT outcomes are similar to conferences in that they require an agreed-upon action plan that may include a formal apology, community work or financial compensation. If the young person complies with all action plan conditions the matter is disposed of without a conviction being recorded against the youth.

\section{DISCUSSION AND CONCLUSIONS}

The UNCRC sets out comprehensive minimum standards for the treatment of all children and its introduction has resulted in the establishment of a "near global consensus that all children have a right to protection, to participation, to personal development and to basic material provision" (Muncie, 2008, p.45). One of the core principles underpinning these rights (and the standards set in subsequent Arti- cles) is the notion of best interests of the child; that is, in all decision concerning children, a primary or greater consideration is acting in the child's best interests. This paper has considered how the best interests principle has been articulated in Australian State and Territory legislation for young people who come into conflict with the law. What this analysis reveals is an alarming degree of disparity between the various jurisdictions in their application of Article 3.

A breakdown of the percentage inclusion of best interests principles for each jurisdiction is provided in Table 5. South Australia is the least compliant with the tenor of Article 3, its interpretation by the UN Committee on the Rights of the Child, and the principles of restorative justice. In fact, the only reference to best interests in this legislation is that relating to due process (i.e., the right to legal advice and representation). Moreover, while reference is made to the need for compensation and restitution to the victims of crime, the legislation fails to frame this in a way that is consistent with the values inherent in restorative justice paradigms (Wundersitz \& Hunter, 2005). Juvenile justice legislation in both territories (ACT and NT) are UNCRC-orientated, but in the case of the ACT, its Crimes (Restorative Justice) Act serves to somewhat undermine gains made in the Children \& Young People Act. The strongest representation of the best interests principle, by way of its juvenile justice charter, is found in the Queensland legislation.

However, representation, does not necessarily translate into practice. Consider the principle which stipulates that liberty deprivation (i.e., custody or detention) should be used as a last resort. Not only is there considerable discrepancy between jurisdictions in terms of the number of juveniles detained in custody, these discrepancies cannot be explained in terms of a failure to enshrine the principle in the relevant legislation. In 2007, the lowest rate of detention following conviction was in Victoria (9 per 100,000) where the principle is not endorsed and the highest rate in the Northern Territory (127.9) per 100,000) where it is (see Taylor, 2009). And while the Queensland legislation has the strongest representation of best interest principles, its rate of 32.2 per 100,000 is equivalent to the remaining three jurisdictions where the principle is also not endorsed ${ }^{12}$. Although the profile differs somewhat for offenders remanded in custody with NSW (131 per 100,000) being highest, Queensland is a close second $(115 \text { per } 100,000)^{13}$. Victoria was equal lowest (at 21 per 100,000) with the Northern Territory. Inconsistencies between legislation and judicial practice raise questions about the extent to which best interests practices are followed in a climate where social control and the management of risk has become a function of particular political imperatives (Goldson \& Muncie, 2006; Hendrick, 2006).

Three omissions in many jurisdictions are of particular concern when one considers the growing trend to "adultify" (Jacobs, 2001) young people. The first is a failure in all but one jurisdiction (ACT) to make best interests a primary consideration in all decisions and actions relating to the young offender. This failure is, of course, consistent with both the current risk discourse (whereby social control rather than

\footnotetext{
${ }^{12}$ For 2007 , the rate per 100,000 were as follows: $\mathrm{ACT}=37.0$; NSW $=38.0$; and SA 36.5

${ }^{13}$ Rates per 100,000 for the remaining jurisdictions are as follows: $\mathrm{ACT}=11 ; \mathrm{SA}=37$; Tasmania $=11 ; \mathrm{WA}=82$.
} 
Table 5. Percentage Inclusion of Best Interests Principle

\begin{tabular}{|c|c|c|c|c|c|c|c|c|c|}
\hline $\mathbf{A C T}^{\mathbf{1}}$ & $\mathbf{A C T}^{\mathbf{2}}$ & $\mathbf{N S W}^{\mathbf{3}}$ & $\mathbf{N S W}^{\mathbf{4}}$ & $\mathbf{N T}$ & QLD & SA & Tas & Vic & WA \\
\hline \hline 75 & 58 & 75 & 45 & 75 & 83 & 41 & 58 & 66 \\
\hline
\end{tabular}

Note: 1 = Children \& Young People Act 2008; 2 = Crimes (Restorative Justice) Act 2004; 3 = Young Offenders Act 1997; 4 = Children (Criminal Proceedings) Act 1987.

social welfare has become the dominant paradigm) and notions of retributivism which seek to make young offenders more accountable for their crimes (Goldson\& Muncie, 2006; Hendrick, 2006), and the emerging trend in many jurisdictions to transfer young people to the adult system for adjudication on the basis of offence severity or the frequency of an individual's offending (Muncie, 2008). Such practices undermine and devalue the very philosophy that underpins a separate system of justice for young offenders. The second glaring omission in much of the legislation reviewed is the failure to acknowledge that the young person's right to dignity and worth is to be promoted and respected. As Van Bueren (1998) has noted, this principle cannot be met when legislation is characterised by general deterrence and punitiveness. Finally, just over half of the legislation reviewed fails to articulate that the needs of the young offender should be a priority. Young offenders are more amenable to treatment and more likely to benefit from rehabilitation efforts than their adult counterparts (Scott \&Grisso, 1997) and, as such, one would expect a focus on the provision of empirically-based rehabilitative services to young people. Unfortunately, this has not been the case in many jurisdictions (see Day \& Casey, 2008). The strengthening of the "get tough" philosophy, in conjunction with politicizing of youth crime, has seen the funding of rehabilitation programs decrease in many jurisdictions. Moreover, despite overall crime rates not increasing to any appreciable extent, there has been an increase in the number of young people detained in custody, a situation which not only contravenes the best interests principle but also Articles 37 (i.e., imprisonment only as a last resort) and 40 (i.e., social reintegration) of the UNCRC.

In conclusion, it would appear that while juvenile justice legislation in Australia serves to ensure that the procedural rights of a young offender are met, much of the legislation does not extend to ensuring that what happens once the young person enters the juvenile justice system is in his or her best interests. The UN Committee on the Rights of the Child has highlighted the irony of the current situation, pointing out that if the system does not protect and guarantee the rights of the child, how can one expect that children, with such a poor example, will respect the human rights and fundamental freedoms of others? There is a need for legislative change that ensures young people who come before the courts have their cognitive, psychosocial and emotional needs considered with respect to the legal process and any subsequent outcomes. In the face of the current trend for adultification and the heavy emphasis on custodial sentences, that legislation should allow for alternative sentencing options that promote pro-social lifestyles and enables the courts to act in a manner that is both therapeutically and procedurally just and equitable.

\section{REFERENCES}

Achtenberg, M. (2000).Understanding restorative justice practice within the Aboriginal context. Forum on Corrections Research, 12, 32-34. Available from http://www.csc-scc.gc.ca/text/pblct/forum/e121/ e121ind-eng.shtml

Blomberg, T.G., \& Lucken, K. (2009). American penology: A history of control. New Brunswick, New Jersey: Transaction Publishers.

Children (Criminal Proceedings) Act 1987. Available from http://www.austlii.edu.au

Children and Young People Act 2008. Available from http://www.austlii.edu.au

Children, Youth and Families Act 2005. Available from http://www.austlii.edu.au

Crimes (Restorative Justice) Act 2004. Available from http://www.austlii.edu.au

Day, A. \& Casey, S. (2008). Review of programmes in youth training centres Part 2: Consultations and Recommendations. Office of the Guardian for Children and Young People. Adelaide, South Australia.

Freeman, M. (2007). Article 3. The best interests of the child. In A. Alen, J. VandeLanotte, E. Verhellen, F. Ang, E. Berghmans\& M. Verheyde (Eds.), A Commentary of the United Nations Convention on the Rights of the Child (pp. 1-75). Leiden, The Netherlands: Martinus Nijhoff Publishers.

Goldson, B., \& Muncie, J. (2006a). Youth crime and justice: Critical issues. London: Sage.

Gottfredson, M., \& Hirschi, T. (1990). A general theory of crime., Stanford, California: Stanford University Press

Hammarberg, T. (2008, May 30). The principle of the best interest of the child - what it means and what it demands from adults. Lecture presented at the Building a Europe for and with children - Towards a Strategy for 2009-2011 conference, Strasbourg, France. Retrieved from https://wcd.coe.int/com.instranet.InstraServlet?Index=no\&command=c om.instranet.CmdBlobGet $\&$ InstranetImage $=900685 \&$ SecMode $=1 \&$ Do $\mathrm{cId}=1283798 \&$ Usage $=2$

Hendrick, H. (2006). Histories of youth crime and justice. In B. Goldson and J. Muncie (Eds.), Youth crime and justice: Critical issues (pp. 3 16). London: Sage.

Herbermann, C.G. (1913). The Catholic encyclopaedia: An international work of reference on the constitution, doctrine, discipline, and history of the Catholic Church, Volume 12. New York, US: The Encyclopaedia Press.

Judicial Council of California (2006).California Community Justice Project: Restorative conferencing. Retrieved from http://www.courtinfo.ca.gov/ programs/ccjp/documents/resjustbrochure.pdf

Juvenile Justice Act 1992. Available from http://www.austlii.edu.au

Muncie, J. (2008). The 'punitive turn' in juvenile justice: Cultures of control and rights compliance in Western Europe and the USA. Youth Justice, $8,107-121$.

Office of the United Nations High Commissioner. (1990). Convention on the Rights of the Child. Retrieved from http://www2.ohchr.org/english/ law/crc.htm\#art37

Office of the United Nations High Commissioner. (2007). General Comment No. 10 (2007): Children's rights in juvenile justice. Retrieved from http://www2.ohchr.org/english/bodies/crc/comments.htm

Scott, E., \& Grisso, T. (1997). The evolution of adolescence: A developmental perspective on juvenilejustice reform. Journal of Criminal Law and Criminology, 88, 137-189.

Secretary, Department of Health and Community Services v JWB and SMB ("Marion's Case") [1992] HCA 15. Retrieved from http://www.austlii.edu.au/au/cases/cth/high_ct/175clr218.html

Smith, P., Goggin, C., \& Gendreau, P. (2002). The effects of prison sentences and intermediate sanctions on recidivism: General effects and individual differences. (User Report 2002-01). Ottawa: Solicitor General Canada. Retrieved http://www.psepc-sppcc.gc.ca/ publications/ corrections/200201_Gendreau_e.pdf 
Taylor, N. (2009). Juveniles in detention in Australia, 1981-2007. Canberra, Australia: Australian Institute of Criminology.

The National Children's and Youth Law Centre (2004). "What's up croc" Australia's implementation of the Convention on the Rights of the Child (CROC). Retrieved from http://www.ncylc.org.au/croc/allaboutcroc $2 . \mathrm{html}$

United Nations (2009).Multilateral treaties deposited with the SecretaryGeneral: Status as at 1 April 2009, Volume 1, Part 1, Chapters I to VII. US: United Nations Publications.

United Nations Children's Fund (UNICEF) (2006a). Convention on the Rights of the Child: Signature, ratification and accession. Retrieved from http://www.unicef.org/crc/index_30207.html

United Nations Children's Fund (UNICEF) (2006b). Convention on the Rights of the Child. Retrieved from http://www.unicef.org/crc/ index_30229.html

United Nations Children's Fund (UNICEF) (2006c). Children in conflict with the law. Retrieved from http://www.unicef.org/protection/files/ Conflict_with_the_Law.pdf
United Nations Children's Fund (UNICEF) (2008). Convention on the Rights of the Child: Understanding the Convention on the Rights of the child. Retrieved from http://www.unicef.org/crc/index_understanding.html

Van Bueren, G. (1998). The international law on the rights of the child. Kluwer Law International, The Hague: The Netherlands.

Wundersitz, J., \& Hunter, N. (2005). Juvenile justice in South Australia: Where are we now? Office of Crime Statistics and Research. Retrieved from http://www.ocsar.sa.gov.au/docs/information_bulletins/IB40.pdf

Wyness, M. (2001). Children, childhood and political participation: Case studies of young people's councils. The International Journal of Children's Rights, 9, 193-212.

Young Offenders Act 1993. Available from http://www.austlii.edu.au Young Offenders Act 1994. Available from http://www.austlii.edu.au Young Offenders Act 1997. Available from http://www.austlii.edu.au Youth Justice Act 1997. Available from http://www.austlii.edu.au Youth Justice Act. Available from http://www.austlii.edu.au Zehr, H. (1990). Changing lenses. Scottsdale, Pennsylvania: Herald Press.

(C) Coppins et al.; Licensee Bentham Open.

This is an open access article licensed under the terms of the Creative Commons Attribution Non-Commercial License (http://creativecommons.org/licenses/by-nc/3.0/) which permits unrestricted, non-commercial use, distribution and reproduction in any medium, provided the work is properly cited. 